To cite this Article: S. Luojus, S. Kauppinen, J. Lahti (2016) UNIVERSITY - AN ESSENTIAL PART OF THE OPEN INNOVATION FRAMEWORK?, ICERI2016 Proceedings, pp. 1158-1170.

DOI: $10.21125 /$ iceri.2016.1263

URL: https://library.iated.org/view/LUOJUS2016UNI 


\title{
UNIVERSITY - AN ESSENTIAL PART OF THE OPEN INNOVATION FRAMEWORK?
}

\author{
Satu Luojus, Sami Kauppinen, Janne Lahti \\ Laurea University of Applied Sciences (FINLAND)
}

\begin{abstract}
Societal challenges such as the ageing population, inequality, energy security and others are global and transnational in nature. During the last years inclusive, innovative and reflective societies have started to search for a solution for societal challenges by promoting new forms of innovation and systematic engagement of citizens in the innovation process. However, the creation of a new kind of innovation culture requires broad cooperation of public administrations, organizations, companies,
\end{abstract} NGOs, universities, and creative individuals.

Service design is seen as a significant driver for sustainable innovation regarding services as means for societal transformation. Service design approach provides methods and tools, not only for engaging citizens into open innovation process, but also for supporting both the designers and the citizens in their creativity and interpretations during the design process.

This paper describes an experiment that addresses developing an elective study unit in service design at Laurea University of Applied Sciences. The objectives of the development work were: (1) to provide students with competence to use diverse development methods and tools flexible at all stages of the service design process; (2) to create sustainable social innovations in co-operation with citizens, public administrators, the third sector, companies, and technology developers; and (3) to create an open innovation process model to involve multidisciplinary students, citizens, companies, and the public and third sectors in the development of digital services.

Action research was chosen as the research strategy for this development work due to its practical and hands-on nature. Action research changes things, not just to add academic knowledge. It is relevant that the researcher parties participate in the development process that proceeds in cycles. A cycle of action research consists of four phases: (1) planning, (2) acting, (3) observing and (4) reflecting. This study consists of three cycles.

The development work was conducted during the multidisciplinary master's degree service design studies (2015-2016) in a project called WeLive (www.welive.eu). The WeLive project was devised to transform the current e-Government approach by facilitating a more open model of design, production and delivery of public services leveraging on the collaboration between the public sector, citizens and entrepreneurs. WeLive applies the service design approach to deliver next generation personalised digital services to citizens. For that, it contributes with the WeLive platform, an ICT infrastructure where stakeholders collaborate in the ideation, creation, funding and deployment of new digital services.

The outcomes of the development work were (1) an improved teaching model in line with the service design process, with the aim of providing students with the ability to act as service designers and innovation processes developers, and (2) an open innovation process model to involve universities (multidisciplinary students), citizens, companies, and the public and third sectors in the development of public services and to facilitate rich interaction between citizens/communities and other stakeholders.

Keywords: service design, open innovation process, digital service, higher education.

\section{INTRODUCTION}

Societal challenges such as the ageing population, inequality, energy security and others are global and transnational in nature. They cannot be addressed by any government, institution, or discipline acting alone. These fundamental challenges imply a need for the modernisation of public administration by taking advantage of digitalization. The eGovernment approach is seeking to promote digital interaction between government and citizens, employees, companies, as well as other government agencies [1]. According to The Edition of the EU eGovernment $9^{\text {th }}$ Benchmark report 
(2010) "service transformation paradigm is requirement that citizens and business, rather than administrative entities, must be focus of the service provision" [2]. The current public services are structured following an administration-centric approach instead of according to the citizens' needs and wishes. Therefore, the European eGovenrment Action Plan (2010) proposes that future services in public sector are needed to design, produce and deliver according to a more open model by involving and empowering citizens, companies and civil society within [3]. The user-centered approach "will lead to a greater availability of services and improved service delivery, including greater personalisation of services, greater speed of delivery, more convenient access to services and longer hours of availability" [2]. However, creation of a new kind of innovation culture requires tools, new competence (eSkills) and operating models that support communication and co-creation between different actors in society.

A Horizon 2020 project "A new concept of public administration based on citizen co-created mobile urban services" (WeLive) aims to transform the current administration-centered approach to build public services more into an open innovation process that enables easy involvement of citizens, employees, companies, and public administrators. The project applies the service design approach with methods and tools to deliver next generation personalised digital services for citizens. For that, the project will create the WeLive platform, an ICT infrastructure where stakeholders collaborate in the ideation, creation, funding and deployment of new digital services. The project provides a new WeGovernment ecosystem of platform and tools built on the open data, open services and open innovation paradigms that is easily deployable in different public administrations and which promotes co-innovation of personalized public services through public-private partnership and the empowerment of all the stakeholders to actively take part in the development of the public services.

Societal challenges together with the pressure of public finance require changes in public administration practices. Several actors have been identified (including universities and higher education organizations) and diverse experiments have been carried out, but open innovation activities in the public sector are still relatively scattered and unstructured. These issues raise questions: What kind of role would higher education organizations/universities have in the national innovation system? How can this role be taken into account in the organization of teaching and in the pedagogical solutions? How could the role of the university in the national innovation system be supported by the organization of teaching and teaching/learning methods? This is exactly the issue our development work attempts to address. The development work focuses not only on educational and pedagogical issues, but also on outlining a new open innovation model of citizen and other stakeholder (public administration, companies, NGOs, universities, etc.) participation in the development of public services.

\section{PUBLIC SERVICE INNOVATION THROUGH OPEN COLLABORATION}

Innovation activity in the public sector has increased rapidly in the last 30 years [4]. However, the traditional government-centric approach to solve fundamental problems and innovate new public services has questioned. As a consequence in recent years the government-centric top-down approach has been turned upside down into a more open users-centered approach, where various stakeholders in a city context are invited to participate and collaborate with each other. This trend is going to intensify in the future because public innovation is placed high on the political agenda in many countries [5].

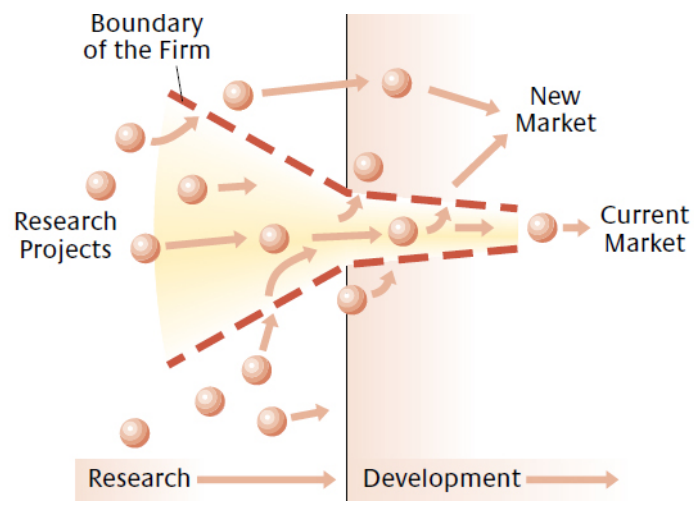

Fig. 1. Open innovation process presented by Chesbrough [6]. 
The open innovation process (Fig. 1) presented by Chesbrough (2003) has provided a framework for the private sector to involve external actors as a part of their internal innovation process [6]. Several examples presented by Nambisan (2008) show that the private sector has successfully implemented external networks and communities to solve problems and accelerate their innovation initiatives. Companies have also created open ecosystems and platforms that are easy to access and aims to create benefit for all participants. [7]. On the other hand, the public sector has followed the private sector's example and started involving citizens into collaborative innovation process. Citizens' engagement to city planning is not a new idea. Arnstein (1969) described the ladder of citizen engagement in his publication. These eight steps of the ladders describe the extent to which citizens can participate in the design, and especially in the related decision-making. The steps from lowest to highest are as follows; 1) manipulation, 2) therapy, 3) informing, 4) consultation, 5) placation, 6) partnership, 7) delegated power and 8) citizen control. Citizens in the lowest two steps have limited or no possibility of influence. The following three steps are degrees of tokenism, which means that citizens have possibility to express their opinions and receive information, but it does not have a significant effect on the decision-making. The top three steps are the degrees of citizen power. At this level, citizens have the opportunity to influence the design and the related decision-making. [8]. SaadSulonen (2014) describes the engagement of citizens with a four-level model. In the first level citizens do not participate, which means the innovation process is administration-centric. In the second level citizens are invited to test and give feedback, which allows developers to create services that fit the needs of users. In the third level citizens collaborate by planning and developing new public services. In the fourth level citizens are an important part of service planning, development and implementation. [9].

According to Jaeger (2011) the concept of innovation however differs in the aspects of objectives and rationales when it is transferred from the private sector to the public sector. Innovations activities in the private sector promote the idea of economic growth while in the public sector the aim is to meet commonly agreed goals [10]. In addition, innovation process in the public sector is hugely driven by social and political actors and various problems and demands in current society [11]. Therefore public sector innovation urges collaborative interaction between citizens but also different stakeholders like public and private actors, politicians, experts, private firms, civil servants, different user groups, interest organizations, universities, and community-based associations [4]. Different actors' roles and motivations to participate vary, which is important to understand.

The city of Helsinki, as a forerunner, is currently developing a city-level model of citizen participation. The city has recently involved around 200 ordinary citizens, public servants, researchers and persons who actively participate in NGO activities, into a co-creation workshop. The aim of the co-creation workshop was to outline the main lines and elements of a new model of citizen participation into the public decision-making in Helsinki. The result was eight drafts of the new model of citizen participation. All the models shared common understanding of the main requirements for the model, which are: transparency, accessibility, intelligibility.

\section{THE PROCESS AND METHODS OF THE DEVELOPMENT WORK}

Service design approach is seen as a significant driver for sustainable innovation regarding services as means for societal transformation. Service design approach provides methods and tools for supporting both the designers and the citizens in their creativity during the design process.

The pedagogical starting point for the development work was a pedagogical model, Learning by Developing (LbD), that is based on learning through research and developing (R\&D). The development work was conducted during the multidisciplinary master's degree service design studies in the WeLive project. The objectives of the development work was: (1) to provide students with competence to use diverse development methods and tools flexible at all stages of the service design process; (2) to create sustainable social innovations in co-operation with citizens, public administrators, the third sector, companies, and technology developers; and (3) to create an open innovation process model to involve citizens, multidisciplinary students, companies, universities, and the public and third sectors in the development of public services.

The development work was carried out during six separate implementations of the study unit called User-Centered Design of Digital Service in 2015-2016. The assignment given to the three-person student groups was twofold: (1) to involve user groups in the service design process of digital services, and (2) to create a new digital service concept that meets the needs, hopes and wishes of the users. During the study unit, the students worked on three levels: (1) studying the service design 
process, methods, and tools, as well as their theoretical backgrounds; (2) applying the theory in practice; and (3) evaluating the theory, models, development process, practice, and tools.

On all implementations of the study unit, work progressed according to the Double Diamond service design process model, developed by the British Design Council (Fig. 2). The design process has been divided into four overlapping phases; (1) In the Discovery phase the designer identifies the problems, needs and opportunities to be addressed through design and builds a rich knowledge base with inspiration and insights [12]. In order to reach deeper understanding of potential users' and stakeholders' needs, hopes and wishes regarding future digital services, the student groups carried out user studies. They applied service design methods and tools to involve citizens, companies, and the representatives of public and third sectors in the design process of digital services. Based on the data gathered they identified the design limitations and opportunities. (2) The Define stage is kind of a filter in which the outputs of the previous phase are analyzed and the findings are synthesized into a limited number of opportunities [12]. The student groups analyzed the qualitative data gathered in the previous phase and synthetized the findings into a reduced number of opportunities. Based on the results and findings of the user studies the students outlined new digital service concepts. Several visualization tools and techniques were used to outline the new ideas and new digital service concepts. The student groups gathered initial feedback on the digital service concepts. The main activities in (3) the Definition phase are to develop the initial brief into a service for implementation, to design service components in detail and as part of the holistic experience, and finally to iteratively test concepts with users [12]. Based on the feedback gathered the student groups further developed their digital service concepts in more detail. In order to iteratively test (e.g. interaction, usability and graphic) their concepts with users they produced the first paper and functional prototypes. In the last phase, (4) the Deliver stage, the final concepts are taken through final testing, signed-off, and produced. [12]. The final service concept was presented to the WeLive project partners, potential end users and other stakeholders (e.g. companies, public and third sector representatives) in the WeLive seminar. With the student groups' consent, the decision on the technical implementation of the digital service concepts created by the student groups was left to the public administration and company representatives. A couple of the student groups have decided to set up companies to further develop their concepts.

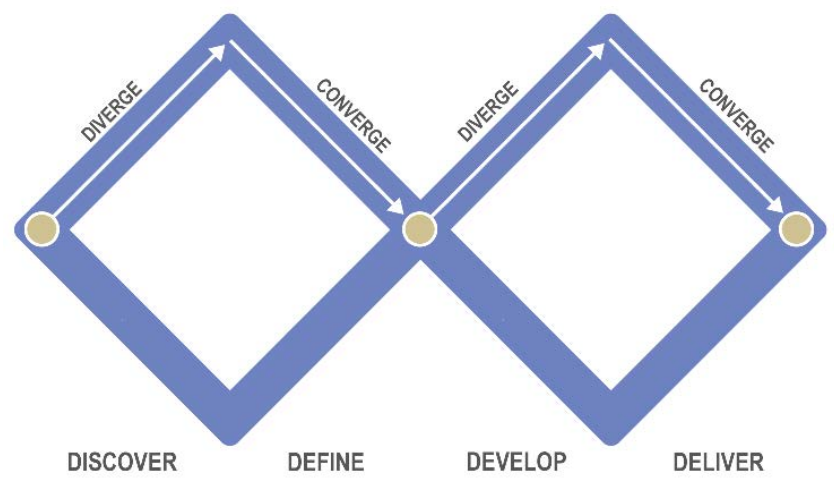

Fig. 2. The Double Diamond process by British Design Council [12].

At the end of the study unit, the student groups evaluated the theory, models, development process, practice, and tools they used in their final reports. The students considered a broad development assignment (OT3) a good way to learn. Below are some examples of the feedback they gave on the study unit:

- "Project work is a very good way to learn. It forces people to turn theory into practice

- "Learning by doing. The other members of my group were already skilled in service design, so I learned a lot from them as the project went along. The teachers' lectures were also clear and contained relevant issues"

- "The assignments were all really meaningful, each task different in its own way but suited the overall package of the study unit. The concrete way in which assignments, especially OT3 were implemented supported the learning process the best".

Action research was chosen as the research strategy for this development work due to its practical and hands-on nature. According to Rapoport (1970) action research aims to contribute both to the 
practical concerns of people in an immediate problematic situation and to the goals of social science by joint collaboration within a mutually acceptable ethical framework [13]. Action research is an iterative approach, combining theory and practice. Iterative and reflective process allows action (e.g. change, improvement) and research (e.g. understanding, knowledge) to be achieved at the same time. $[14,15]$. In other words, action research changes things, not just to add academic knowledge.

There are four basic steps in the action research cycle: (1) plan, (2) act, (3) observe and (4) reflect. These steps are repeated in sequence as work progresses, creating an upward spiral of improving practice. The following figure (Fig. 3) illustrates the progress of cyclic action research. This development work consists of three action research cycles, during which the aim is to not only develop educational or pedagogical issues, but also to outline a new open innovation model for developing public services. In the following tables the steps of each three action research cycles, their objectives and partners involved are explained in more detail.

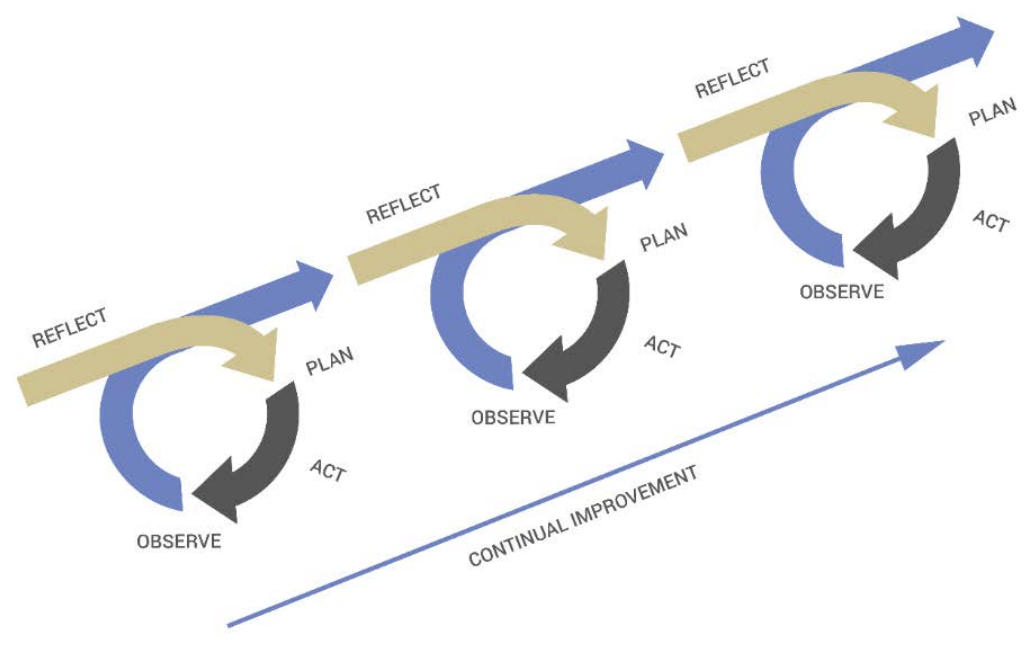

Fig. 3. The four basic steps in the cyclic action research approach.

The first cycle of action research. The first two implementations of the study unit were carried out between September and December 2015. The assignments were intended to promote the development of public digital services that profit citizens. Co-operation was begun with the City of Vantaa. The general challenges of digitalizing public services presented from the city's perspective were not made concrete enough in the assignment. The city's role as a partner still remained distant.

Table 1. Illustrates the steps of the first cycle of action research.

\begin{tabular}{|c|c|c|c|c|}
\hline Cycle & Step & $\begin{array}{l}\text { Partners of the university of applied } \\
\text { sciences and the steps }\end{array}$ & Aims of the step & Participants \\
\hline \multirow[t]{2}{*}{$\begin{array}{l}\text { The } \\
\text { first } \\
\text { cycle }\end{array}$} & Plan & $\begin{array}{l}\text { The need for cooperation with city } \\
\text { representatives was taken into account } \\
\text { when planning the implementation of the } \\
\text { study unit. }\end{array}$ & $\begin{array}{l}\text { The assignment on the } \\
\text { study unit was intended } \\
\text { to promote the } \\
\text { development of public } \\
\text { digital services. }\end{array}$ & $\begin{array}{l}\text { The teachers of the } \\
\text { study unit. }\end{array}$ \\
\hline & Act & $\begin{array}{l}\text { City representatives gave an opening } \\
\text { lecture on the challenges of digitalizing } \\
\text { public services and of developing public } \\
\text { services in general from the city's } \\
\text { perspective. The students conducted user } \\
\text { studies and developed new digital service } \\
\text { concepts based on the results. The } \\
\text { students presented the service concepts } \\
\text { they had developed in a WeLive seminar } \\
\text { poster session. City representatives gave } \\
\text { feedback during the seminar on the service } \\
\text { concepts developed. }\end{array}$ & $\begin{array}{l}\text { The assignment on the } \\
\text { study unit was intended } \\
\text { to produce new digital } \\
\text { service concepts in } \\
\text { response to citizens' } \\
\text { needs. }\end{array}$ & $\begin{array}{l}\text { The teachers of the } \\
\text { study unit, } \\
\text { representatives of } \\
\text { the City of Vantaa, } \\
52 \text { Master's degree } \\
\text { students. }\end{array}$ \\
\hline
\end{tabular}




\begin{tabular}{|c|c|c|c|}
\hline Observe & $\begin{array}{l}\text { The teachers of the study unit recorded their } \\
\text { observations on how the implementation } \\
\text { progressed throughout the study unit. The } \\
\text { teachers of the study unit evaluated the } \\
\text { implementation of the study unit and the } \\
\text { results achieved (learning objectives, } \\
\text { grades, the quality of the ideas/products, the } \\
\text { innovativeness of the ideas). }\end{array}$ & $\begin{array}{l}\text { Collect research data for } \\
\text { action research. }\end{array}$ & $\begin{array}{l}\text { The teachers of the } \\
\text { study unit, } 52 \\
\text { Master's degree } \\
\text { students. }\end{array}$ \\
\hline Reflect & $\begin{array}{l}\text { The students received feedback on their } \\
\text { own learning process. The students gave } \\
\text { feedback on the implementation of the study } \\
\text { unit. The teachers went through the } \\
\text { development suggestions which they had } \\
\text { themselves noted and which the students } \\
\text { had expressed for the next implementation }\end{array}$ & $\begin{array}{l}\text { To develop the } \\
\text { implementation of the } \\
\text { study unit and an } \\
\text { operating model with } \\
\text { which the role of an } \\
\text { institution of higher } \\
\text { education can be } \\
\text { strengthened in the } \\
\text { national innovation } \\
\text { system. }\end{array}$ & $\begin{array}{l}\text { The teachers of the } \\
\text { study unit, } 52 \\
\text { Master's degree } \\
\text { students. }\end{array}$ \\
\hline
\end{tabular}

The second cycle of action research. The next two implementations of the study unit were carried out between January and May 2016. When reflecting on the previous implementation of the study unit it was noted that the city's role as a partner should be strengthened and the assignments should be made more concrete. The City of Vantaa presented the students with "city challenges", which are concrete examples of services of different sectors in need of digital solutions. City representatives were closely involved in planning the study unit, guiding the students and giving feedback. The innovativeness and the applicability of the service concepts developed by the students increased significantly. Cooperation with the city began to take shape. After the study unit ended, posters presenting the service concepts developed by the students were put on display in the public library of Vantaa for citizens to comment on.

Table 2. Illustrates the steps of the second cycle of action research.

\begin{tabular}{|c|c|c|c|c|}
\hline Cycle & Step & $\begin{array}{l}\text { Partners of the university of applied } \\
\text { sciences and the steps }\end{array}$ & Aims of the step & Participants \\
\hline \multirow{4}{*}{$\begin{array}{l}\text { The } \\
\text { second } \\
\text { cycle }\end{array}$} & Plan & $\begin{array}{l}\text { The implementation of the study unit was } \\
\text { planned together with city representatives. }\end{array}$ & $\begin{array}{l}\text { The assignment on the } \\
\text { study unit was intended to }\end{array}$ & $\begin{array}{l}\text { The teachers of } \\
\text { the study unit, }\end{array}$ \\
\hline & & $\begin{array}{l}\text { City representatives presented "city } \\
\text { challenges", which are focused assignments } \\
\text { in order to come up with ideas for various } \\
\text { digital service concepts. }\end{array}$ & $\begin{array}{l}\text { produce new digital } \\
\text { service concepts in } \\
\text { response to citizens' } \\
\text { needs. The city } \\
\text { challenges were used to } \\
\text { define the development } \\
\text { areas of digital services } \\
\text { from the cities' } \\
\text { perspective. }\end{array}$ & $\begin{array}{l}\text { representatives of } \\
\text { the City of Vantaa. }\end{array}$ \\
\hline & \multirow[t]{2}{*}{ Act } & $\begin{array}{l}\text { City representatives gave an opening lecture } \\
\text { on the challenges of developing public } \\
\text { services from the city's perspective and } \\
\text { presented the city challenges. The students } \\
\text { conducted user studies and developed new } \\
\text { digital service concepts based on the results. } \\
\text { The students presented the service concepts } \\
\text { they had developed at the end of the study } \\
\text { unit and received feedback from city } \\
\text { representatives. In a WeLive seminar poster } \\
\text { session representatives of the cities and } \\
\text { companies gave feedback on the service } \\
\text { concepts which the student groups had } \\
\text { developed. }\end{array}$ & \multirow[t]{2}{*}{$\begin{array}{l}\text { The assignment on the } \\
\text { study unit was intended to } \\
\text { produce new digital } \\
\text { service concepts in } \\
\text { response to citizens' } \\
\text { needs. Sparring was } \\
\text { requested from the } \\
\text { citizens, city } \\
\text { representatives and } \\
\text { companies to develop the } \\
\text { concepts }\end{array}$} & \multirow[t]{2}{*}{$\begin{array}{l}\text { The teachers of } \\
\text { the study unit, } \\
\text { representatives of } \\
\text { the City of Vantaa } \\
\text { and } 53 \text { Master's } \\
\text { degree students }\end{array}$} \\
\hline & & $\begin{array}{l}\text { The posters were put on display in the city } \\
\text { library and citizens have feedback on the } \\
\text { concepts developed }\end{array}$ & & \\
\hline
\end{tabular}




\begin{tabular}{|c|c|c|c|}
\hline Observe & $\begin{array}{l}\text { The teachers of the study unit recorded their } \\
\text { observations on how the implementation } \\
\text { progressed throughout the study unit. The } \\
\text { teachers of the study unit evaluated the } \\
\text { implementation of the study unit and the results } \\
\text { achieved (learning objectives, grades, the quality } \\
\text { of the ideas/products, and the innovativeness of } \\
\text { the ideas). }\end{array}$ & $\begin{array}{l}\text { Collect research data for } \\
\text { action research. }\end{array}$ & $\begin{array}{l}\text { The teachers of the } \\
\text { study unit, } 53 \\
\text { Master's degree } \\
\text { students. }\end{array}$ \\
\hline Reflect & $\begin{array}{l}\text { The students received feedback on their own } \\
\text { learning process. The students received } \\
\text { feedback on the service concepts they had } \\
\text { developed from city representatives and citizens. } \\
\text { The students gave feedback on the } \\
\text { implementation of the study unit. The teachers } \\
\text { went through the development suggestions } \\
\text { which they had themselves noted and which the } \\
\text { students had expressed for the next } \\
\text { implementation. }\end{array}$ & $\begin{array}{l}\text { To develop the } \\
\text { implementation of the study } \\
\text { unit and an operating } \\
\text { model with which the role } \\
\text { of an institution of higher } \\
\text { education can be } \\
\text { strengthened in the } \\
\text { national innovation system. }\end{array}$ & $\begin{array}{l}\text { The teachers of the } \\
\text { study unit, } 53 \\
\text { Master's degree } \\
\text { students, city } \\
\text { representatives and } \\
\text { citizens. }\end{array}$ \\
\hline
\end{tabular}

The third cycle of action research. The last two implementations of the study unit started in the beginning of September 2016. When reflecting on the previous implementation of the study unit it was noted that co-operation with the city works well and is appropriate. The "city challenges" have made the assignments more concrete and the support of and sparring with city representatives has helped the students to gain better learning results than before. The aim is to extend co-operation towards companies and the third sector. City representatives were closely involved in planning the study unit, guiding the students and giving feedback on the service concepts developed. Both parties feel they benefit from the co-operation. Business partners (especially developers of digital technology) were also invited to plan and implement the study unit and to evaluate the products. According to the student feedback received thus far and the partners' assessment more extensive co-operation appears fruitful.

Table 3. Illustrates the steps of the third cycle of action research.

\begin{tabular}{|c|c|c|c|c|}
\hline Cycle & Step & $\begin{array}{l}\text { Partners of the university of applied } \\
\text { sciences and the steps }\end{array}$ & Aims of the step & Participants \\
\hline \multirow[t]{2}{*}{$\begin{array}{l}\text { The } \\
\text { third } \\
\text { cycle }\end{array}$} & \multirow[t]{2}{*}{ Plan } & $\begin{array}{l}\text { The implementation of the study unit was } \\
\text { planned together with city representatives. } \\
\text { City representatives presented the students } \\
\text { with "city challenges", which are focused } \\
\text { assignments in order to come up with ideas } \\
\text { for various digital service concepts, and } \\
\text { companies interested in implementing them. }\end{array}$ & $\begin{array}{l}\text { The assignment on the study } \\
\text { unit was intended to produce } \\
\text { new digital service concepts in } \\
\text { response to citizens' needs. } \\
\text { The city challenges were used } \\
\text { to define the development } \\
\text { areas of digital services from } \\
\text { the cities' perspective. }\end{array}$ & \multirow[t]{2}{*}{$\begin{array}{l}\text { The teachers of } \\
\text { the study unit, } \\
\text { representatives } \\
\text { of the City of } \\
\text { Vantaa and the } \\
\text { companies }\end{array}$} \\
\hline & & & $\begin{array}{l}\text { Company partners functioned } \\
\text { as sparring partners in } \\
\text { concept development. }\end{array}$ & \\
\hline
\end{tabular}

Act City representatives gave an opening lecture on the challenges of developing public services from the city's perspective, presented the city challenges and the partner companies.

The students conducted user studies and developed new digital service concepts based on the results. The students presented the service concepts they had developed during the study unit and received feedback from representatives of the city and the companies. In a WeLive seminar poster session representatives of the cities and companies and a panel of citizens gave feedback on the service concepts which the student groups had developed. After the study unit ends, the posters will be put on display in the Vantaa city library to be commented on by the citizens.
The assignment on the study unit was intended to produce new digital service concepts in response to citizens' needs. Feedback was collected from citizens, city representatives and companies during the development of the service concepts.
The teachers of the study unit, representatives of the City of Vantaa and partner companies, citizens and 30 Master's degree students 


\begin{tabular}{|c|c|c|c|}
\hline \multirow[t]{3}{*}{ Observe } & $\begin{array}{l}\text { The teachers of the study unit recorded their } \\
\text { observations on how the implementation } \\
\text { progressed throughout the study unit. }\end{array}$ & $\begin{array}{l}\text { Collect research data for } \\
\text { action research. }\end{array}$ & \multirow{3}{*}{$\begin{array}{l}\text { The teachers of } \\
\text { the study unit, } \\
30 \quad \text { Master's } \\
\text { degree } \\
\text { students. }\end{array}$} \\
\hline & $\begin{array}{l}\text { The teachers of the study unit evaluated the } \\
\text { implementation of the study unit and the } \\
\text { results achieved (learning objectives, grades, } \\
\text { the quality of the ideas/products, the } \\
\text { innovativeness of the ideas). }\end{array}$ & & \\
\hline & The students conducted a self-assessment. & & \\
\hline Reflect & $\begin{array}{l}\text { The students received feedback on their own } \\
\text { learning process. The students received } \\
\text { feedback on the service concepts they had } \\
\text { developed from representatives of the city } \\
\text { and partner companies as well as from } \\
\text { citizens. The students gave feedback on the } \\
\text { implementation of the study unit. The } \\
\text { teachers went through the development } \\
\text { suggestions which they had themselves } \\
\text { noted and which the students had expressed } \\
\text { for the next implementation }\end{array}$ & $\begin{array}{l}\text { To develop the implementation } \\
\text { of the study unit and an } \\
\text { operating model with which } \\
\text { the role of an institution of } \\
\text { higher education can be } \\
\text { strengthened in the national } \\
\text { innovation system. }\end{array}$ & $\begin{array}{l}\text { The teachers of } \\
\text { the study unit, } \\
30 \quad \text { Master's } \\
\text { degree } \\
\text { students, } \\
\text { citizens, } \\
\text { representatives } \\
\text { of the city an } \\
\text { companies. }\end{array}$ \\
\hline
\end{tabular}

The collaboration within national and international partner network in the R\&D projects provide a new, motivating dimension for studying. The multidisciplinary learning environment offers the students a wider and more varied group of experts to discuss and spar with to develop digital service concepts than on a traditional study unit implementation. This appeared to promote reaching learning objectives. The results achieved by students during the cycles of the development work exceed the targets set for their studies. Moreover, public administration and companies, as well as the R\&D project, benefit from employing students' multidisciplinary competences to enrich their R\&D activities.

\section{THE RESULTS OF THE DEVELOPMENT WORK}

The most important outcomes of the development work were (1) an improved teaching model with the aim of providing students with the ability to act as service designers and innovation processes developers, and (2) an open innovation process model to involve universities (multidisciplinary students), citizens, companies, and the public and third sectors in the development of public services and to facilitate rich interaction between citizens/communities and other stakeholders.

The first version of the teaching model was created during the first cycle of the action research process [16]. We have iteratively developed the model further through the development work. The new teaching model (Fig. 4) is based on and follows the phases defined in the Double Diamond process model. In the teaching model citizens are invited to participate in an open innovation process in co-operation with multidisciplinary students, companies, the public and third sectors. The model describes parallel progression of the learning process and the service design process, which aims at the conceptualization of a digital public service. For this reason all the phases of the process define diverse objectives for the service design and for learning processes. 

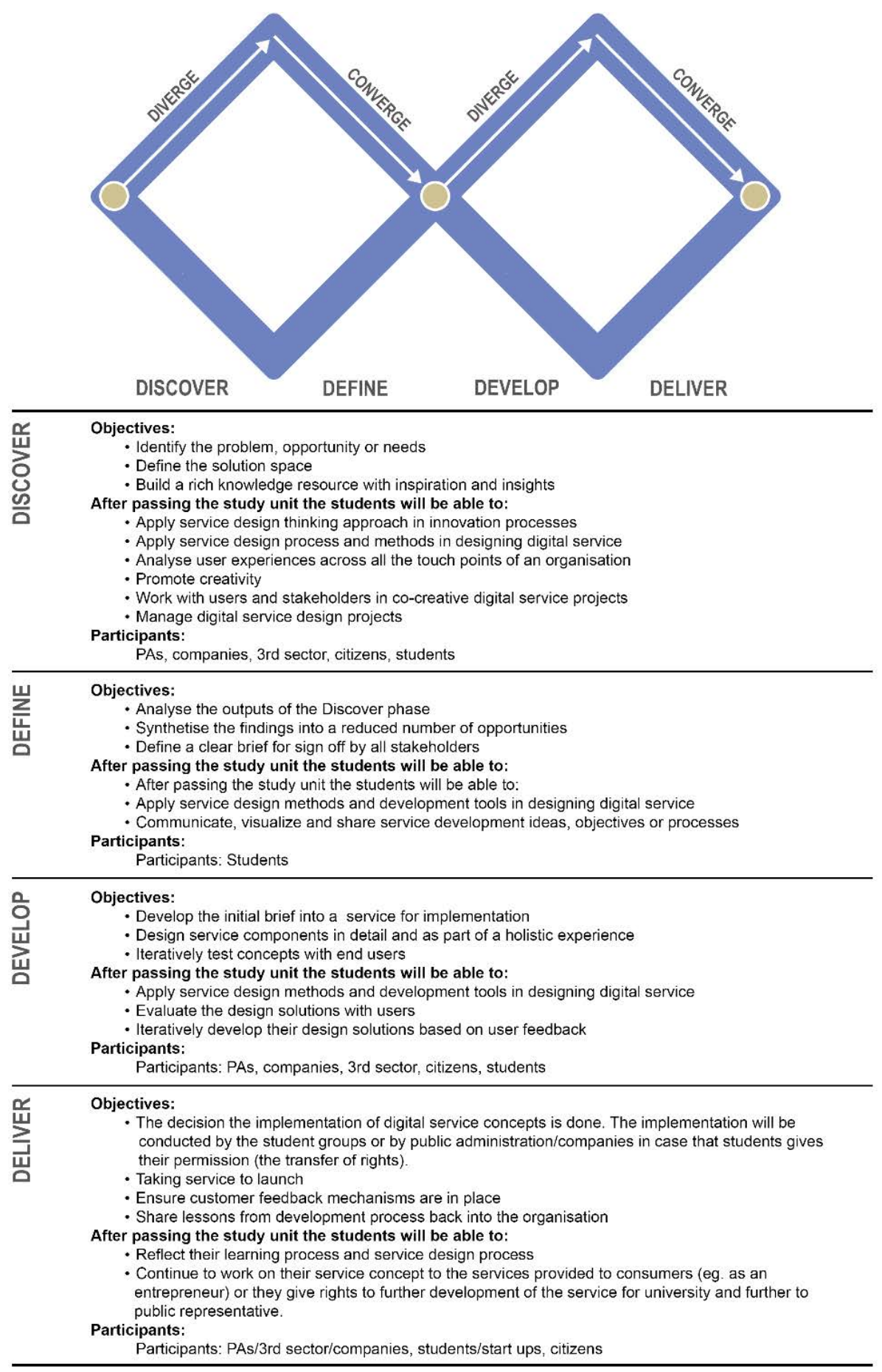

Fig. 4. The new teaching model.

In the new open innovation process for the public sector (Fig. 5), citizens are involved from the beginning, in partnership with the public sector, companies, start-ups, universities, organisations and students. The new open innovation process will focus on transferring the ideas from innovation to adoption, by democratizing the service creation process and fostering public-private partnership that will jointly exploit the outcomes of the open innovation process. 


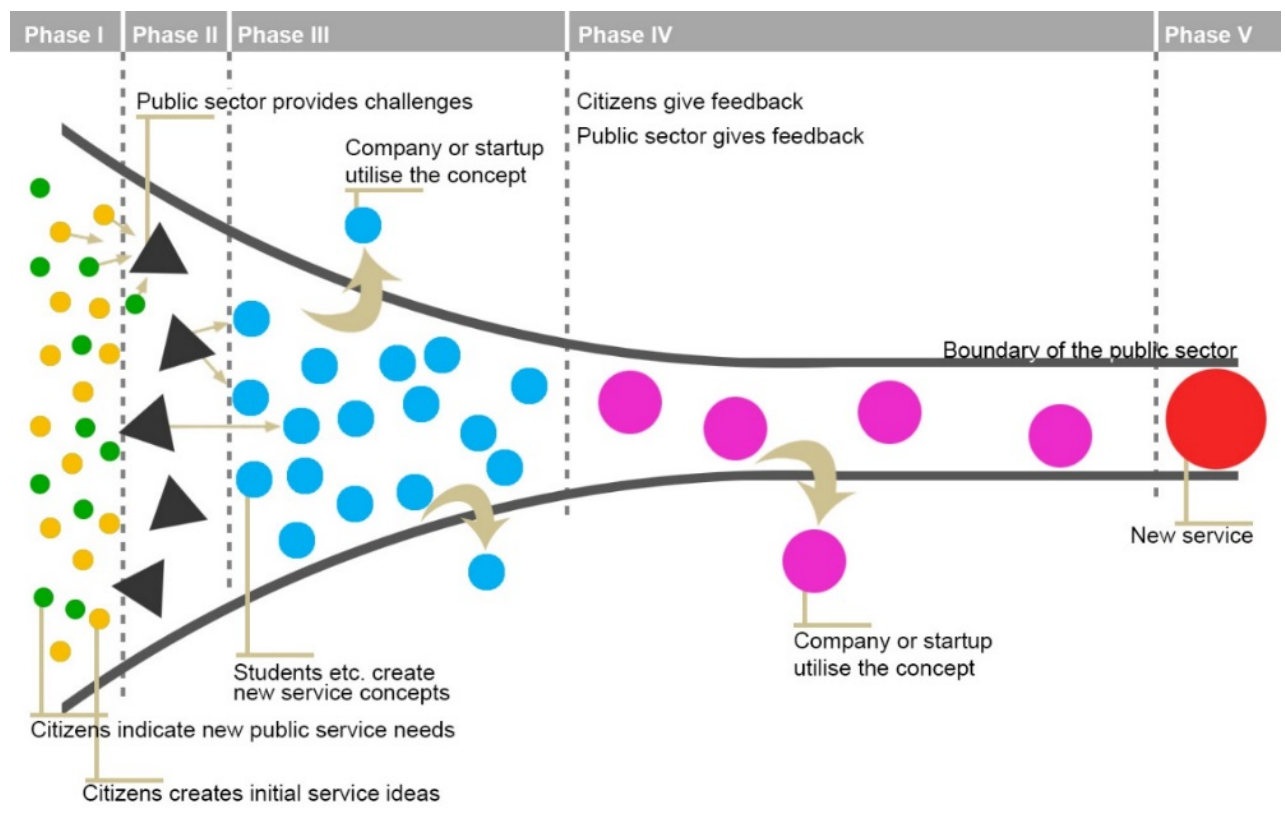

Fig. 5. New open innovation process for the public sector

The phases of the public innovation process for public sector is described in Table 4. It consist of five phases: I) First the public sector utilizes user-centered methods to understand the needs that different target groups have for public services. II) The public sector formulates challenges based on the user information gathered. The open innovation process provides a lot of information and ideas about new services. However, at the same time it requires from the public sector the ability to distinguish valuable information from irrelevant information. Higher education can provide expertise and resources to evaluate the data and contribute to the "city challenges". III) Different actors create solutions to the challenges presented. It is important that the public sector provides participants possibilities (e.g. platform) to collaborate with each other and citizens to give feedback. IV) The public sector decides the services that will be developed and $\mathrm{V}$ ) finally implemented.

Table 4. Phases of the open innovation process aim for public sector.

\begin{tabular}{l|l}
\hline Phases & Description \\
\hline Phase I & $\begin{array}{l}\text { Citizens indicate their needs, hopes and wishes and create initial ideas about new public } \\
\text { services. The public sector utilizes different user-centric methods to gather user information. }\end{array}$ \\
\hline Phase II & $\begin{array}{l}\text { The public sector formulates challenges based on citizens' needs/hopes/wishes and initial } \\
\text { service ideas. The challenges are published through online platform. }\end{array}$ \\
\hline Phase III & $\begin{array}{l}\text { University students, citizens, developers and start-ups create solutions for challenges provided } \\
\text { by public sector. Public sector creates exhibitions and invites citizens to give feedback. }\end{array}$ \\
\hline Phase IV & $\begin{array}{l}\text { Have decided that this is a good concept and the development of the new service starts. } \\
\text { Public sector is funding if it is part of their core services }\end{array}$ \\
\hline Phase V & Implementation of the new public service \\
\hline
\end{tabular}

Citizens, the public sector, companies, new start-ups, universities, organizations and students are invited to collaborate in different phases of the public service delivery. The following Table 5 summarises different roles of the participants in the public sector open innovation process. 
Table 5. Different roles of the participants in the public sector open innovation process.

\begin{tabular}{|c|c|}
\hline Part & fferent roles in the public sector open innovation process \\
\hline $\begin{array}{l}\text { Citizens (e.g. } \\
\text { service } \\
\text { consumer, } \\
\text { idea creator, } \\
\text { developer ) }\end{array}$ & $\begin{array}{l}\text { - Indicate their needs, hopes and wishes and create initial service ideas } \\
\text { - Participate in the idea contests / hackathons created by public sector } \\
\text { - } \quad \text { Vote for the best service ideas and concepts } \\
\text { - } \quad \text { Provides crowd-funded investment to foster the interesting service ideas }\end{array}$ \\
\hline & $\begin{array}{l}\text { - Orchestrates the open innovation process and facilitates the platform and tools of the } \\
\text { ecosystem } \\
\text { - } \quad \text { Facilitates democratic thinking by involving citizens and other stakeholders to 'bottom } \\
\text { up' approach } \\
\text { - } \quad \text { Identifies socio-economic challenges and provides challenges as a starting point for the } \\
\text { innovation process } \\
\text { - } \quad \text { Provides Open Data to support novel service application creation } \\
\text { - } \quad \text { Organizes contests / hackathons to motivate and facilitate innovative use of open data } \\
\text { - } \quad \text { Launches calls for developers for big projects that are important for the community } \\
\text { - } \quad \text { Provides funds for the most potential service ideas that helps to reduce the squeeze of } \\
\text { public finance }\end{array}$ \\
\hline Cor & $\begin{array}{l}\text { - Exploit the ideas that have spilled outside boundaries of the open innovation process } \\
\text { - } \quad \text { Participate in the contests and calls created by public sector } \\
\text { - } \quad \text { Utilize Open Data provided by public sector } \\
\text { - } \quad \text { Provide their data for other to exploit } \\
\text { - } \quad \text { Get finance for their service ideas }\end{array}$ \\
\hline New & $\begin{array}{l}\text { - Participate in the idea contests / hackathons created by public sector } \\
\text { - Utilize Open Data provided by public sector } \\
\text { - } \quad \text { Get finance for their service ideas }\end{array}$ \\
\hline Unive & $\begin{array}{l}\text { - Provide process for the public innovation process } \\
\text { - } \quad \text { Provide co-creation tools for public sector to involve citizens and other stakeholders in } \\
\text { the open innovation process } \\
\text { - } \quad \text { Provide service design tools to manage the whole service delivery process } \\
\text { - } \quad \text { Help public sector to analyze the user data and refine the ideas }\end{array}$ \\
\hline Organisations & $\begin{array}{l}\text { - } \quad \text { Provide latent information about specific user groups } \\
\text { - } \quad \text { Give feedback about ideas, concepts and planned services }\end{array}$ \\
\hline $\begin{array}{l}\text { Students (e.g. } \\
\text { concept } \\
\text { designer, } \\
\text { developers) }\end{array}$ & $\begin{array}{l}\text { - Participate from the beginning in the open innovation process to discover and define } \\
\text { socio-economic challenges, and develop initial ideas in an iterative process } \\
\text { - } \quad \text { Analyse and refine the ideas created by citizens } \\
\text { - Potentially take their service ideas further in the implementation phase } \\
\text { - Utilise new competence (e.g. eSkills) how to innovate digital public services together } \\
\text { with citizens, companies and public administration } \\
\text { - Encourage their working life to benefit the ideas that have spilled outside of the } \\
\text { innovation process's boundaries } \\
\text { - Exploit the ideas that have spilled outside boundaries of the open innovation process }\end{array}$ \\
\hline
\end{tabular}

The whole innovation process needs to be open and transparent from the beginning to the end. Citizens are able to see and comment on the services developed at any point of the process. Some ideas and concepts can be spilled out from the funnel. In those cases the company or start-up will utilize the concept or idea. They also funded the idea development. 


\section{DISCUSSION}

The purpose of our development work was (1) to elaborate the role of universities in the national open innovation system, (2) to outline a new teaching model to support universities participation in the national innovation system, and (3) to outline a new open innovation process model to involve universities (multidisciplinary students), citizens, companies, and the public and third sectors in the development of public services. The most important outcomes of the development work were (1) an improved teaching model, and (2) the public sector open innovation process model.

We have identified several challenges and possibilities regarding universities' participation in the national innovation system applying open innovation process. Many challenges associated with the organization of cooperation between the different actors have been identified: (1) PA's engagement and favorable attitude towards new open innovation approach and real development work is crucial; (2) integrative and linking personas/officials/employees and "hubs" are needed to communicate with different actors; (3) the key action takes place on a virtual open platform (e.g. WeLive platform) and/or an open physical space (e.g. the Living Lab), where citizens, municipal employees and students can collaborate needs to available; (4) intellectual property rights in open innovation process have to be defined so that they are fair to all actors in the system; and (5) open innovation process produces a lot of valuable information, but at the same time it requires the operator the ability to distinguish relevant information from irrelevant. In addition, a competence to combine the information from outside the organization's own operations is needed. After all, participation in open innovation processes and platforms will increase and diversify the competence of the teachers and the students. Moreover, it provides students with authentic, topical and appropriate assignments and thus opportunities to develop their competences also in new areas of expertise.

Neither the teaching model nor the open innovation process model to involve universities in the national innovation system presented in this paper is by no means complete; it is more like the first step. It is, however, the authors' hope that it could serve to open up and advance the discussion within the higher educational field further.

\section{REFERENCES}

[1] Jeong Chun Hai @Ibrahim. (2007). Fundamental of Development Administration. Scholar Press: Selangor.

[2] Capgemini, IDC, Europe Rand, DTi \& Sogeti (2010). Digitizing Public Services in Europe: Putting ambition into action - 9th Benchmark Measurement.

[3] European Commission (2010). The European eGovernment Action Plan 2011-2015 Harnessing ICT to promote smart, sustainable \& innovative Government. COM(2010) 743.

[4] Borins, S. (2001). Encouraging innovation in the public sector. Journal of intellectual capital, 2(3), 310-319.

[5] Newman, J., Raine, J., \& Skelcher, C. (2001). Developments: Transforming local government: Innovation and modernization. Public Money and Management, 21(2), 61-68.

[6] Chesbrough, H. (2003). The era of open innovation. MIT Sloan Management Review, 44(3), 3541.

[7] Nambisan, S. (2008). Transforming government through collaborative innovation. Public Manager, 37(3), 36.Miettinen, S. and Valtonen, A. (eds.) (2012) Service Design with Theory: Discussion on Value, Societal Change and Methods. Lapland University Press: Rovaniemi.

[8] Arnstein, S. R. (1969). A Ladder of Citizen Participation. JAIP, 35(4), July 1969, 216-224.

[9] Saad-Sulonen, J. (2014). Combining participations. Expanding The Locus Of Participatory EPlanning By Combining Participatory Approaches In The Design Of Digital Technology And In Urban Planning. Doctoral Dissertation. Aalto University School of Arts, Design and Architecture: Helsinki.

[10] Jaeger, B. (2011). User-Driven Innovation in the Public Service Delivery. Working paper No: 4/2011. CLIPS - Collaborative innovation in the Public Sector. Roskilde University.

[11] Sørensen, E., \& Torfing, J. (2011). Enhancing collaborative innovation in the public sector.

[12] British Design Council. http://www.designcouncil.org.uk (Retrieved 15.6.2015) 
[13] Rapoport, R. N. (1970). Three dilemmas of action research. Human Relations, 23, 499-513.

[14] Avison, D. E., Lau, F., Myers, M. D., \& Nielsen, P. A. (1999). Action research. Communications of the ACM, 42(1), 94-97.

[15] Baskerville, R., \& Wood-Harper, T. (1996). A critical perspective on action research as a method for information systems research. Journal of Information Technology, 11(3), 235-246.

[16] Luojus, S., Kauppinen, S., \& Lahti, J. (2015). Integrating teaching and R\&D in higher education - The WeLlve project. In Proceedings of the 8th International Conference of Education, Research and Innovation. pp. 5497-5507. 